\section{CHEMISTRY}

\section{Instant steam from sunlight}

Nanoparticles that efficiently absorb light energy and convert it into heat can act as miniature steam generators in a liquid.

Naomi Halas, Peter

Nordlander and their colleagues at Rice University in Houston, Texas, used lenses to focus sunlight on carbon or gold-silica nanoparticles suspended in water. Within a few seconds, steam at a temperature well above $100^{\circ} \mathrm{C}$ was generated around the particle surfaces and bubbled away, whereas the bulk of the water heated up only gradually.

This method of using sunlight to generate hightemperature steam could be used to sterilize waste or surgical instruments without the need to boil a large volume of fluid, the authors suggest. The same effect may improve distillation: sunlight focused on nanoparticles in an ethanol-water mixture produced vapours richer in ethanol than conventional thermal distillation.

ACS Nano http://dx.doi. org/10.1021/nn304948h (2012)

\section{PALAEONTOLOGY}

\section{Fossil hints at star's salty past}

Modern echinoderms -invertebrates such as brittlestars and sea urchins - live only in open seas, but fossils from Europe suggest that this has not always been the case.

A team led by Mariusz Salamon of the University of Silesia, Poland, examined fossils of the Aspiduriella similis brittlestar from a quarry in southern Poland. The fossils were embedded in limestone dated to the Middle Triassic period, more than 240 million years ago. Minerals and geological structures within the rocks suggest that the fossils formed in conditions with very high salt levels, such as those present in hypersaline coastal waters. Few other fossils were found in the rock, also pointing to harsh living conditions. Echinoderm fossils have been used as indicators of open marine environments, something the authors caution against.

PLoS ONE 7, e49798 (2012)

BIOLOGY

\section{Switching off cancer resistance}

Modern therapies can target specific pathways in cancer cells, but the cells often become drug resistant. René Bernards of the Netherlands Cancer Institute in Amsterdam and his colleagues have identified a gene involved in resistance, and have found a way to stop it in its tracks.

Resistance can be caused by mutations in genes or proteins that are not directly targeted by a drug. Bernards' team used a genetic technique called RNA interference to investigate the effects of shutting down thousands of human genes.

The researchers found that when the gene MED12 was switched off, the cells in a variety of cancers became resistant to a range of anticancer drugs. Suppressing this gene activates the transforming growth factor $\beta$ receptor (TGF- $\beta \mathrm{R}$ ) and, conversely, inhibiting the signalling through this receptor in drug-resistant cells eliminates the resistance. Cell 151, 937-950 (2012)

\section{OPTICS \\ Technology for thinner probes}

A single optical fibre could form the basis of thinner endoscopes - long imaging probes with medical, military and industrial uses.

Current endoscopes are made up of millimetre-sized bundles of up to 100,000 fibres. Each fibre transports a single mode of light wave coming from the object being imaged, because the mixing of modes can cause light-wave distortion.

COMMUNITY CHOICE

The most viewed papers in science

\title{
Cancer-drug infertility reversed
}

\section{HIGHLY READ \\ on www.cell.com in November}

Transplanted testicular stem cells can restore fertility to macaque monkeys made infertile by chemotherapy.

Kyle Orwig at the University of

Pittsburgh in Pennsylvania and his colleagues took stem cells capable of developing into sperm from macaques and marked them with a lentivirus. After inducing infertility in the 12 adult and 5 prepubescent donors, the researchers returned the marked cells to the animals. Marked genetic material later appeared in the sperm of nine of the adults, and three of the juveniles when they reached maturity.

The team then ran a similar experiment, transplanting cells from the donors into other macaques. Of six adult recipients, two produced sperm from transplanted donor stem cells. Moreover, donor-derived sperm from one recipient successfully fertilized eggs to produce embryos with a donor father. Cell Stem Cell 11, 715-726(2012)

Wonshik Choi at Korea University in Seoul and his colleagues have used a single 200-micrometre-wide fibre to transport multiple modes, by measuring and reverse engineering the distortion that each mode suffers. The authors used their technique to make a three-dimensional map of a sample of rat intestine.

Phys. Rev. Lett. 109, 203901 (2012)

\section{PALAEONTOLOEY}

\section{Birds of a different feather}

The wings of ancient birds and feathered dinosaurs that lived some 150 million years ago may have been less like those of modern birds than previously thought.

Contemporary birds share a common wing design, with a single feather layer. But Nicholas Longrich of Yale University in New Haven, Connecticut, and his colleagues identify separate layers in their fossil analyses of the wings of the Jurassic bird Archaeopteryx lithographica (pictured) and

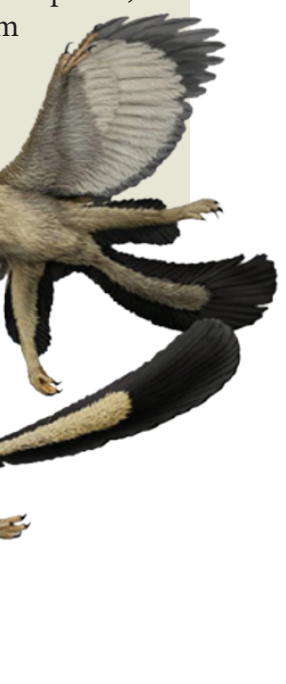

the Cretaceous feathered dinosaur Anchiornis huxleyi.

The slender feather shafts found in these prehistoric plumages would make the feathers weak by modern standards but, when stacked, may have formed a structure strong enough to generate lift. However, the layers would have limited the airflow through the wing, which is used by modern birds for take-off and low-speed flight, so these prehistoric flyers probably glided or parachuted down from trees, the authors say. Curr. Biol. http://dx.doi. org/10.1016/j.cub.2012.09.052 (2012)

\section{$\rightarrow$ NATURE COM}

For the latest research published by Naturevisit:

www.nature.com/latestresearch 